Academy of Management Annual Meeting Proceedings includes abstracts of all papers and symposia presented at the annual conference, plus 6-page abridged versions of the "Best Papers" accepted for inclusion in the program (approximately 10\%). Papers published in the Proceedings are abridged because presenting papers at their full length could preclude subsequent journal publication. Please contact the author(s) directly for the full papers.

\section{Social Entrepreneurship and}

\section{Empowerment: Safe Space and Bridging In The Case Of MadeInCarcere}

Luca Mongelli, Pietro Versari, Francesco Rullani and Antonino Vaccaro

Published Online: 30 Nov 2017 |

https://doi.org/10.5465/ambpp.2016.14219abstract

\section{Abstract}

The empowerment of marginalized individuals implies solutions both affecting the conditions which impede self-determination and stimulating the individuals to take choices. In Italy, for instance, social enterprises working with convicts have to deal with a repressive context and a lack of individual agency mind-set. Our paper presents the results of a case study of Made In Carcere, an social enterprise actives in Lecce which employs convicted women to produce and sell products on the market. We examine how the empowerment of convicts passes through the creation of a safe space and processes able to make a bridge with the outside reality. Our paper demonstrates that the market driven dimension of social enterprise is critical to make the bridging effective in producing convicts empowerment, other than make the organization economic sustainable.
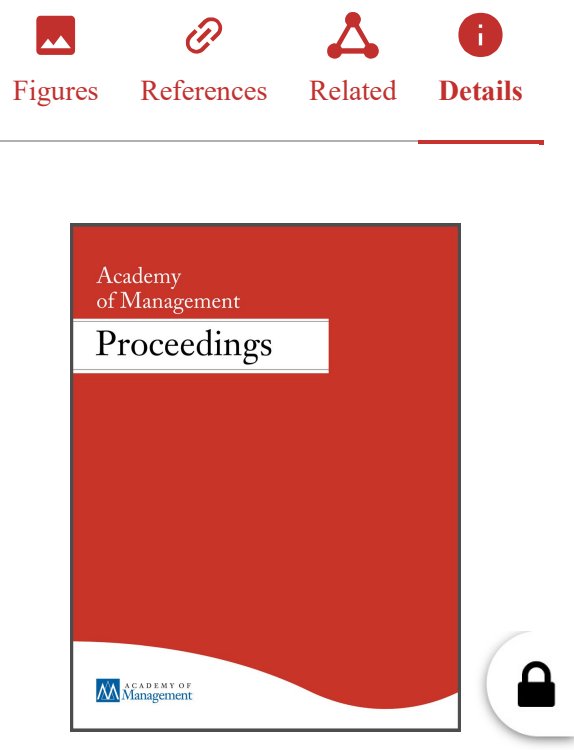

Vol. 2016, No. 1

\section{Permissions}

\section{Metrics}

Downloaded 0 times in the past 12 months

\section{History}

Published online 30 November 2017

Published in print 1 January 2016

\section{Information}

Copyright of Academy of Management Journal is the property of Academy of 


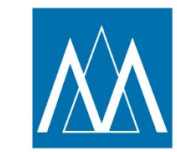

A C A D E M Y O F
Management

Academy of Management

555 Pleasantville Road,

Suite N200

Briarcliff Manor, NY

10510-8020, USA

Phone: +1 (914) 326-1800

Fax: +1 (914) 326-1900

Privacy Policy Logo Use

(C) 2020 Academy of Management

Powered by Atypon ${ }^{\circledR}$ Literatum 